\title{
Biomechanical model of cerebral vascular dynamics and their effect on CSF dynamics
}

\author{
Christine Goffin”, Lukas Theisgen, Klaus Radermacher \\ From Hydrocephalus 2015 \\ Banff, Canada. 18-21 September 2015
}

With advancing age venous wall thickness increases going along with a loss of elastic properties, the arterioles curl and capillary density decreases leading to a reduction of cross sectional area [1]. Even in healthy individuals these changes influence vascular and CSF dynamics, as a reduction of total cerebral blood flow, aqueduct and cervical stroke volume are reported [2]. In $\mathrm{NPH}$ these dynamics seem to be altered in a different way, as aqueduct stroke volume [2] and ICP amplitude are increased and arteriovenous delay is drastically reduced compared to normal aging [3]. However it is not clear in what way the described vascular alterations influence the pressure propagation inside the vessels and impact CSF dynamics.

So far no biomechanical model exists that investigates the influence of macroscopic and microscopic changes of cerebral blood vessels. That is why we put a model up for discussion that simulates vascular pressure propagation and enables the investigation of altered vascular properties in the context of NPH.

A Matlab Simulink model was developed reproducing each vessel section by a distensible compartment. Therefore the cerebral vascular tree was divided into 13 sections from carotid artery to venous sinuses and the pulsatile carotid artery and sinus pressure were inputted as Fourier series. The cross sectional area was varied according to literature data and flow resistance was implemented taking into account the rheological characteristics of blood. The Windkessel function and relaxation properties of vascular walls were integrated by a Voigt model, enabling the variation of wall properties for each section individually. Due to the distensible vessel walls each section interacts with the CSF compartment and autoregulation was implemented by a simple proportional controller. After parameterisation mean

* Correspondence: goffin@hia.rwth-aachen.de

RWTH Aachen University, Germany 
11. Elixmann I, Walter M, Goffin C, Hahne S, Kiefer M, Leonhardt S:

'Hirndruckmodellierung und Regelung einer neuen mechatronischen externen Ventrikeldrainage', at-Automatisierungstechnik. 2011, 59(10):613-621.

doi:10.1186/2045-8118-12-S1-P14

Cite this article as: Goffin et al:: Biomechanical model of cerebral vascular dynamics and their effect on CSF dynamics. Fluids and Barriers of the CNS 2015 12(Suppl 1):P14.

Submit your next manuscript to BioMed Central and take full advantage of:

- Convenient online submission

- Thorough peer review

- No space constraints or color figure charges

- Immediate publication on acceptance

- Inclusion in PubMed, CAS, Scopus and Google Scholar

- Research which is freely available for redistribution

Submit your manuscript at www.biomedcentral.com/submit 